Klára KudLOVÁ

Univerzita Karlova

\title{
The Human and the Non-Human in Ze života hmyzu by the Brothers Čapek: Contexts, Scheme, Interpretation
}

One of the highly relevant questions of today is that of the relationship between humankind and nature in terms of their parallels, but also in the terms of their division and difference. The employment of their contrast and mirroring was present in artistic literature from antiquity on: as a channel of allegorical expression and personification at certain times, as a means of realistic plotting at others, later as a starting point of essayistic reasoning, or as a self-enclosed symbol in an emblematic discourse.

\section{Ze života hmyzu by the Brothers Čapek and Its Critical Contents}

In the wake of the Czechoslovak democracy, brothers Josef (1887-1945) and Karel (1890-1938) Čapek joined to write a play about insects and humans, one published eventually in 1921 as Ze života hmyzu/From Insects' Life and premiered on April 8, 1922. The period in which they wrote displayed many parallelisms to our present day. Modernity introduced substantial plurality into the creative sphere, there was literally an outburst of various artistic modes; after the Great war, society was in search for new political and social models, and the scientific self-esteem was shaken by the relative helplessness of humanity face to face with the Spanish flu. The feeling that new order needs to be found was immense, and it was the strongest in the context of the new democratic republic of Czechoslovakia. 
The Čapeks' artistic contribution in this situation was a rather untypical one. When drafting their play, they combined comedy, fable, expressionist grotesque and morality, and portrayed the processes of erotic preying, piling up of stocks, inevitable hunting and killing and territorial fight of the insects. In its third act, the drama was also highly anti-militaristic. Both the critics and the audiences understood the play's subtle criticism of the pre-war and early post-war Czechoslovak society. Such critique was not often performed on the classical theatre stages of the very new Czechoslovakia, but was-for the time being-restrained to variety theatres (Opelík 2017: 210).

The social and political critique, however, did not exhaust the complex thematic core of the play. Its Prologue and Epilogue contained dramatic meditation on the nature of humanness, pronounced and embodied in the poetic figure of Tulák/Wanderer. In this protagonist, the drama explored not only the finiteness of human existence, but also its transcendental rooting and significance of participation in the everyday.

The performance in the National Theatre in Prague immediately won major public acclaim, and within the first decade, the drama was repeatedly staged in a number of cultural centres. The play was translated into English, German, Hungarian, Italian, Japanese, Chinese, and into Polish-by Maria Bunikiewicz-and premiered in New York, Berlin, London, Vienna, Tokyo, Warsaw, Sydney and many other cities.

While the audience and readers appreciated the rhythm, vivacity, brisk satire and philosophical charge of the drama, the critics and scholars were left with a more difficult task of deciphering the complex interaction between the Wanderer and the insect protagonists of the play. One hundred years after the play was published for the first time, this interaction is still inviting new interpretative approaches.

\section{Contextualising Ze života hmyzu}

The present study seeks the appropriate interpretation of the insect and human figures in From Insects' Life and tries to establish a semantic model of the mutual engagement of the human and non-human in it. In the first step towards these aims, it identifies the intertextual and inter-medial contexts of the play. In the second, it employs its structural analysis.

Since the language of the study is English, there is an obvious need to quote from Ze života hmyzu in an English translation. A major problem, however, lies in the fact there is a substantial lack of complete English translations of the play. During the first fifty years after its writing, the adaptation by Paul Selver and later by Owen Davis were used in the Anglophone world. This praxis was 


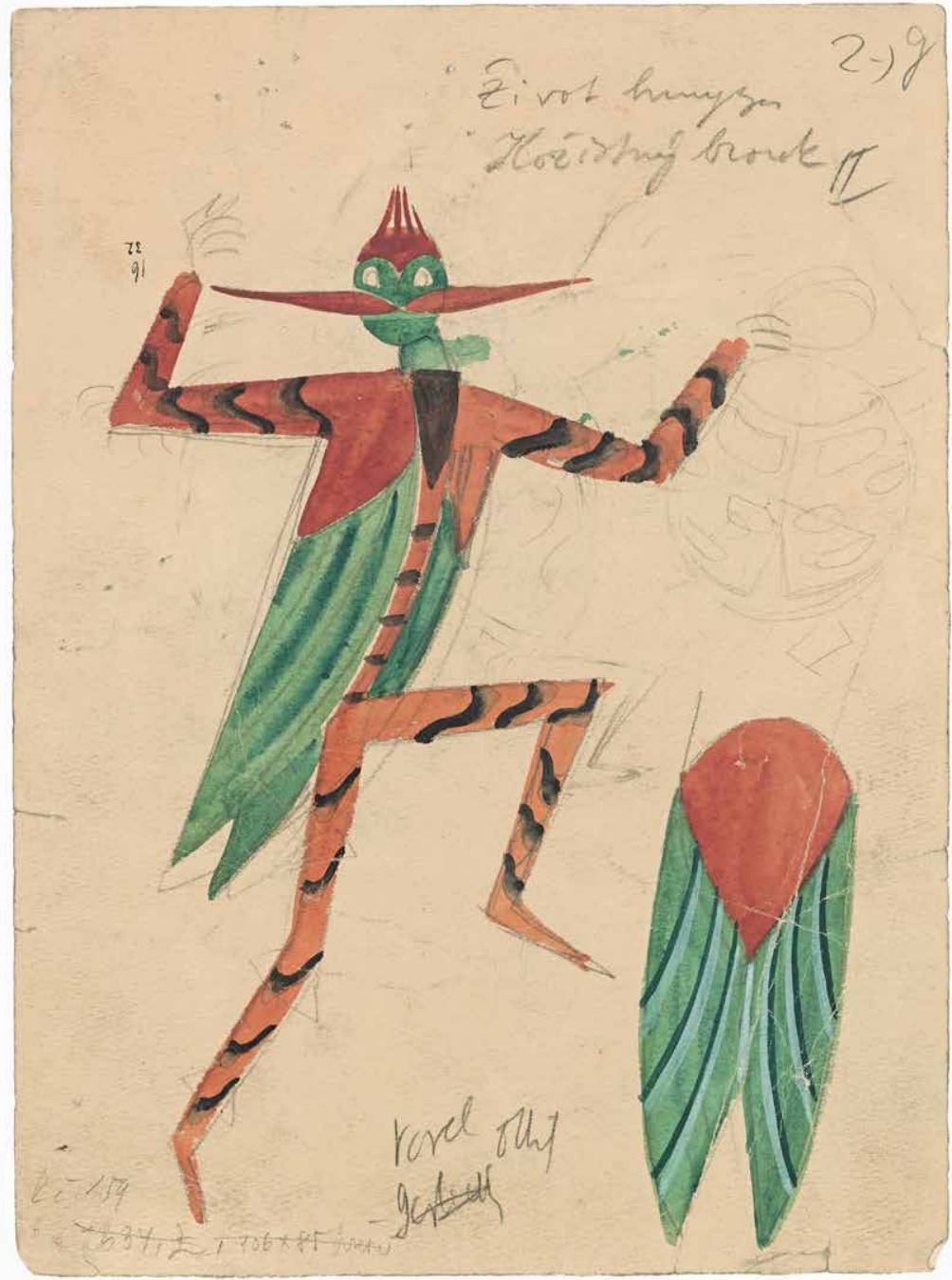

Fig. 1. The sketch of the Looter Beetle II for the first staging of From the Insects' Life by Josef Čapek (The Archive of National Theatre, Prague) 
actually highly problematic. Unfortunately, Peter Majer's and Cathy Porter's translation, while complete and much more faithful, was also substantially amended. Due to this, the quotes from the play and the names of individual characters are translated directly (though not artistically) from the third edition of Ze života hmyzu (1922) by the Brothers Čapek, the first one, which contains both versions of the ending of the play.

During the time of the Brothers Čapek, the tendency to employ non-human protagonists appeared partially in reaction to the minute realistic descriptions of human psyche and body in the realist and naturalist traditions, partially as the outcome of the modernist interest in symbol, allegory and mask.

Anthropomorphised animal and plant characters would appear, e.g., in the famous Chantecler (1910) by Edmond Rostand (1868-1918) or in the philosophical Maikäfer-Komödie (Cockchafer/Beetle Comedy) (1897) by Joseph Viktor Widmann (1842-1911).

\subsection{From Insects' Life and L'Oiseau Bleu}

The most influential drama with animal protagonists during the Čapeks' time was the symbolist L'Oiseau Bleu (Blue Bird) (premiered September 30, 1908) by Maurice Maeterlinck (1862-1949), a drama quite close to From Insects' Life in its structural plan.

The questing children in L'Oiseau Bleu are accompanied by a personified Cat and Dog, as well as other non-human characters, such as Light or Bread. Together, they travel through a series of fantastic environments (the Stationendrama/station drama structure) and encounter many humans, but also many natural and even abstract characters. The natural characters who the children and their companions encounter in the various "steps" are symbolic and belong to the fairy-tale realm. The "encountered" insect characters in From Insects' Life reflect the everyday matters of human life and represent its non-flattering, grotesque, but also tragic aspects.

The "guides" both in L'Oiseau Bleu and in From Insects' Life display symbolic closeness to their pilgrims. In Maeterlinck's drama, the names of the children and of their two animal guides are all derived from the root Tyl, "good" and suggest their potential ontological oneness. The fact that the tomcat Tylette is actually a traitor in the company may be pointing to the capacity of evil even in "the good." In From Insects' Life, a similar complementation takes place between the cocoon, i.e. Kukla or Chrysalis, and the travelling Wanderer. Their unity is both moral (unlike most of the insect figures, they are innocent) and ontological: the Wanderer expresses his interest and his closeness to the Chrysalis: "Chrysalis, 
oh, Chrysalis, I will stick with you!" (Čapkové 1922b: 52). In the Epilogue, the final words and actions of Chrysalis and the Wanderer are parallel. The ecstatic expressions of Chrysalis:

The rule of life / I declare! All creatures I command: / live! For the rule of life is come! ... Harken! Harken! / Great words I am bringing." (Čapkové 1922b: 76) are transformed into a lower stylistic level and repeated by the Wanderer: "I want to - just for a while - I want to - ... Let me live! Just live! ... - I've got so much to tell! - He drops on his knees. - I know now - how - to live. - Collapses. (Čapkové 1922b: 78)

\subsection{From Insects' Life and That Which Was Not}

Roman Jakobson (Jakobson 557-561) and later also František Černý (Černý 107-176) underlined a fable inspiration on insects in the work of the Brothers Čapek and pointed to Vsevolod Mikhaylovitch Garshin and his short story Chego nye bylo (That Which Was Not), published in 1882 in the Russian magazine Ustoj and translated into Czech in 1916. The sets of non-human characters in That Which Was Not and From Insects' Life partially overlap: the characters of Dung Beetle, Ants, Snail and Caterpillar/Chrysalis appear in both works to embody the blind struggle for property and care for posterity, meaningless work, personal indifference and hope in the future respectively.

Both narratives also share a clear-cut philosophical dimension. That Which Was Not is, in this respect, a marvel of terse expression: in the heat of the day, a few animals and insects meet to discuss the purpose of life. Their brief exchange is ended by a coachman, who unknowingly steps on them. The only survivors of this moment, a horse, some flies and a lizard, accept almost too easily the tragedy and finiteness of life.

In her study on Garshin's story, Anna Hendrika Keesmann-Marwitz comments on the number of interpretations the insect figures of the story lend themselves to and points out that the fable "had always remained one of the most concise and yet illustrative vehicles to carry a moral, didactic or political message" (Keesmann-Marwitz 500). The denotative capacity and construction insects in the work of both Garshin and the Brothers Čapek is rooted in dichotomy: the insects and animals either stand for the limited and passing life of natural creatures, or stand for particular human types and their weaknesses and vices. This ambivalence allows the laconic words of the characters to gain substantial semantic scope. 


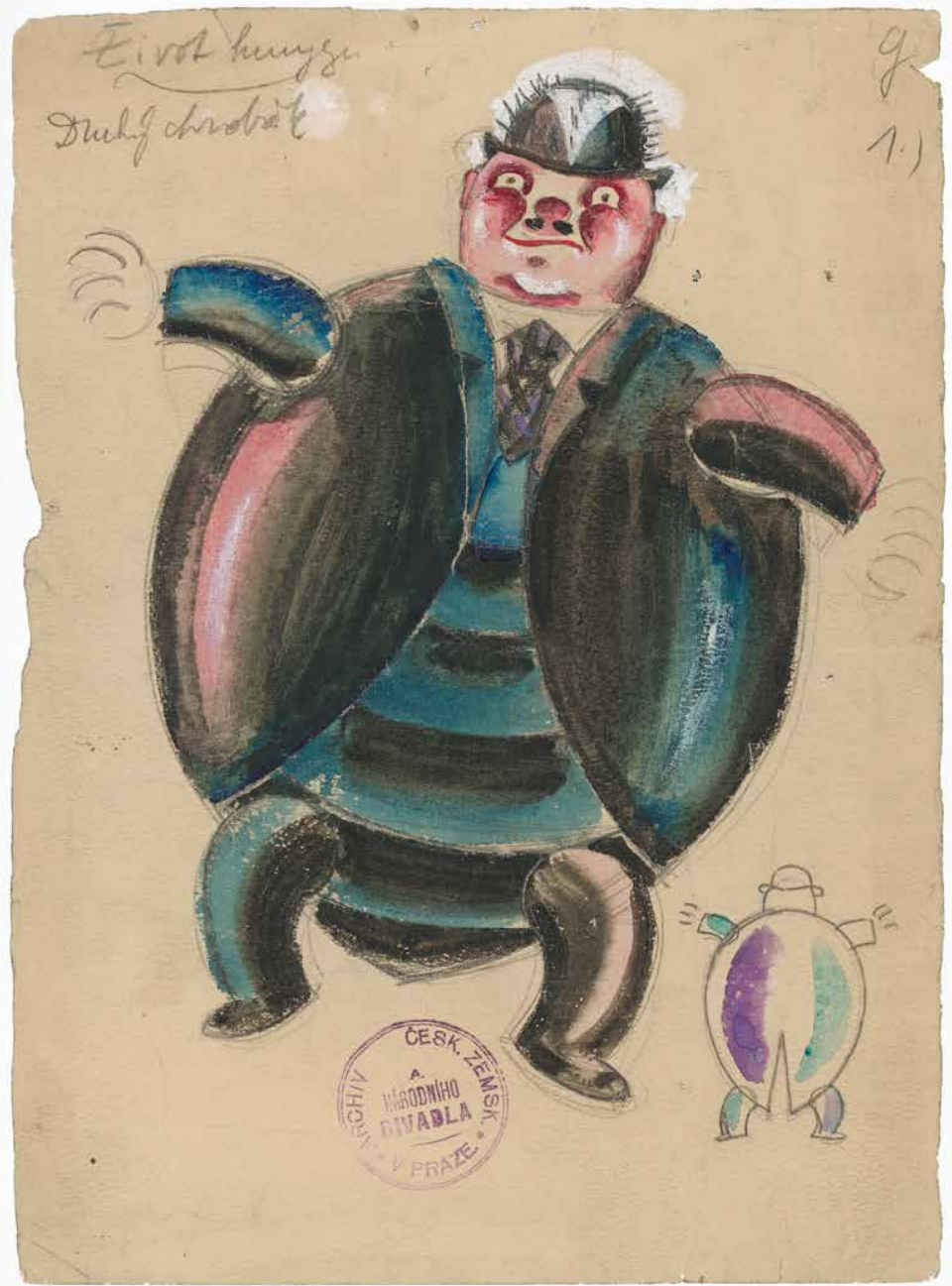

Fig. 2. The sketch of the Second Dung-Beetle figure for the first staging of From Insects' Life by Josef Čapek (The Archive of National Theatre, Prague) 


\subsection{The Visual Aspects of Insects' Characters and Their Artistic Context}

In search for the contexts of insects in the Brothers Čapek, another brief text, one which was so far not available in English, proves to be supremely beneficial. It is the authorial instruction ending the "Dramatis Personae" list. In English it reads:

The DRESSES of insects quite human: in the case of BUTTERFLIES elegant, in the case of MARAUDERS civil, in the case of ANTS black (or yellow) working clothes, MAYFLIES in gauze veils. The insect quality is expressed in the gestures and mimics, yet the characters always remain men and women, except of that which is insect-like in real people. (Čapkové 1922b: 7; capitals Čapeks, italics added)

This note offers a very significant suggestion with regard to the concept of the play's characters, but not only of them (as shown in section 3 ).

The note also generates a strong visual concept of the insects. Josef Čapek, the older of the two authors, was both writer and painter, and provided the first Czech staging of the play (April 8, 1922; the National Theatre in Prague) directed by Karel Hugo Hilar (1885-1935) not only with scenic solutions, but also with sketches, depicting both the costumes and "masks" of the insect characters. The dual aspect of the construction of the natural characters suggested by the authorial note can be easily recognised in these sketches. The faces of the actors are masked so as to resemble insect features; the costumes, however, present typical clothing of the period, just slightly deformed and vividly coloured.

During the pre-war period, Josef Čapek studied at the Academy of Applied Arts in Prague and at Académie Colarossi in Paris, and his approach to fine arts was a deeply premeditated one. As pictor eruditus he was well-acquainted with the baroque and early Renaissance paintings in which the portrayed characters presented a combination of human and non-human features. (Famous examples can be found in the illustrations of De humana physiologia (1586) by Giovanni Batista Della Porta (1535-1615), and in the notorious physiognomies by the French painter Charles Le Brun (1619-1690). Čapek's archived sketches of the insect characters and also the photographs from the premiere staging of From Insects' Life on April 8, 1922 in the National Theatre in Prague prove a conceptual semblance with the above listed physiognomies.

This applies, for example, to the insect character of the Parasite: the actor's head, covered with thick make-up and bristles, resembled that of a caterpillar as the character embodied caterpillar-like morals and gluttony. It also applied to the human character of Pedant (an entomologist), whose face was half-covered by massive goggles, resembling the large eyes of insects, this way 


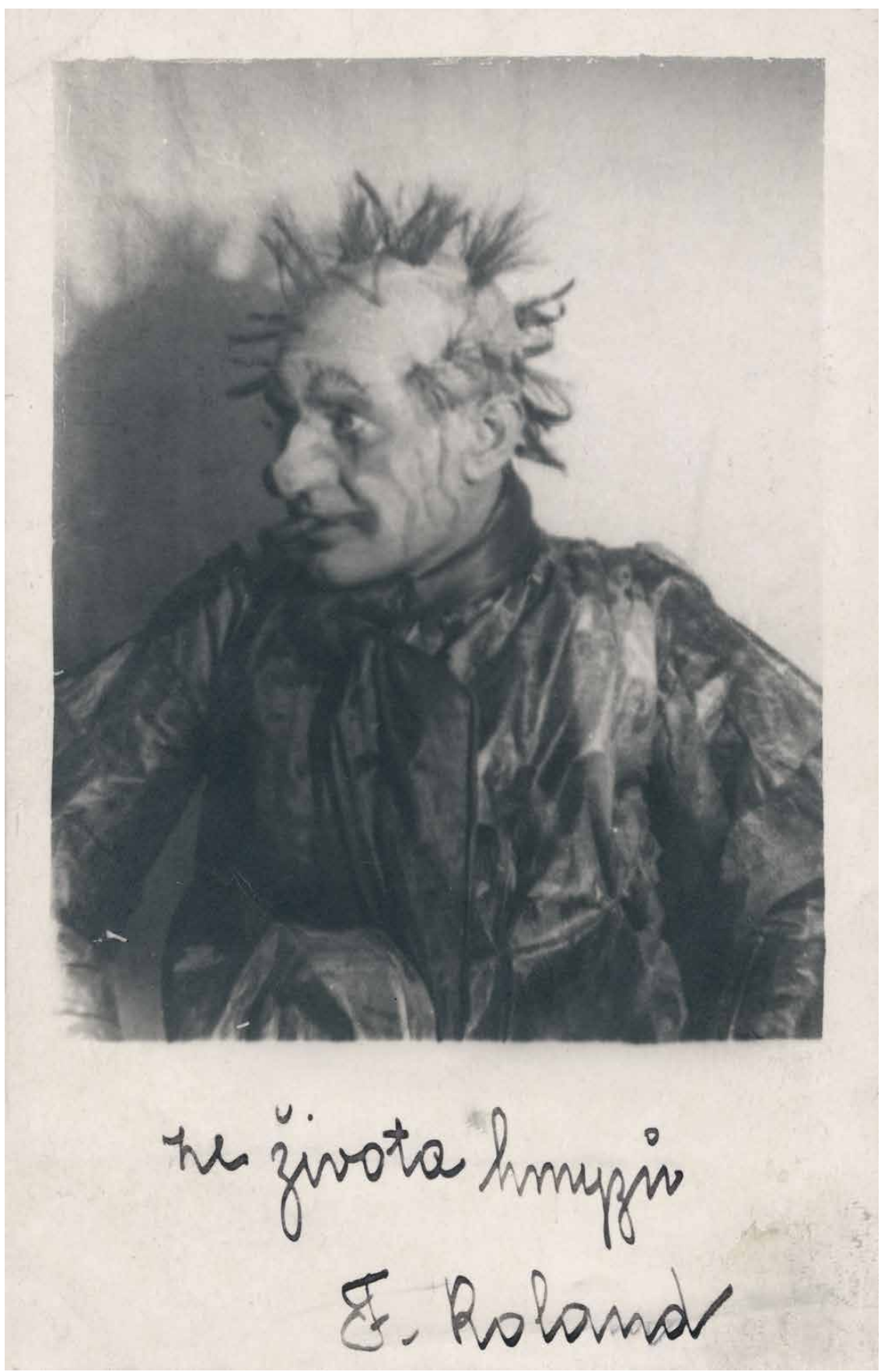

Fig. 3. The photo of Parasite, played by František Roland, April 8, 1922 (The Archive of National Theatre, Prague) 


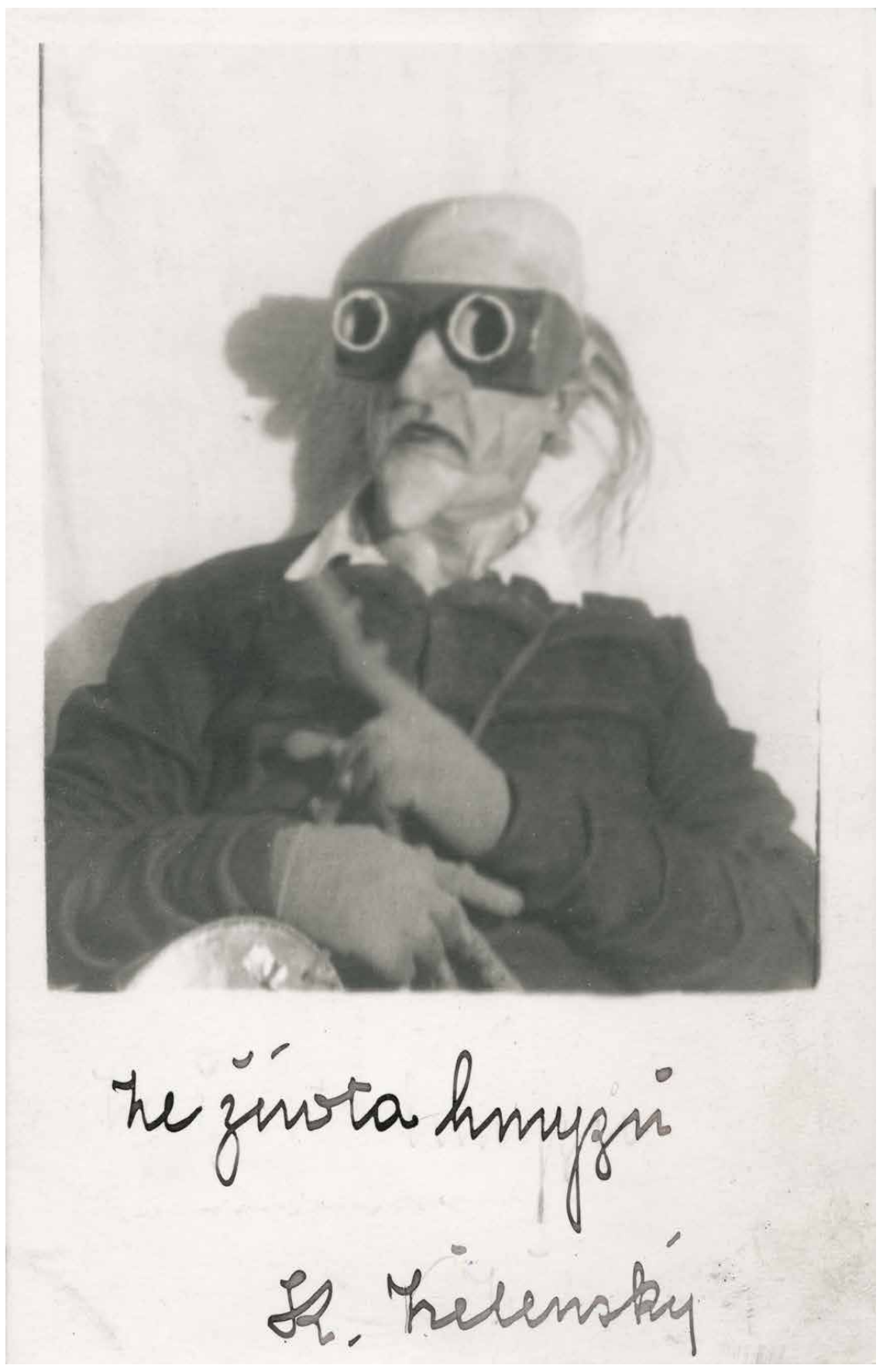

Fig. 4. A photo of Pedant, played by Karel Želenský, April 8, 1922 (The Archive of National Theatre, Prague) 
suggesting both the blending of the human with non-human and Pedant's psychological blindness.

With the stress on the visual, the ambivalence of seeming and being enters the interpretation of the insect characters. Just like Le Brun's humans with faces deformed by, e.g., their erotic over-involvement (the man portrayed as a hog), the Butterflies of Act 1 of Ze života hmyzu derive their essence both from the images of mating insects, driven by their reproductive instinct, and from the human types belonging to the upper society with its trivial flirting, superficial love affairs and cynical life attitude. Nevertheless, it is not just the erotic over-activity which is satirised in those butterfly characters (Iris, Viktor, Oskar). The inability to engage in full male-female relationship (including mating, accepting physical changes in female and bringing up the offspring) is also ridiculed in the characters of the butterfly poet Felix and the abandoned fiancée Clythia.

\subsection{The Expressionist Pre-Texts of From Insects' Life}

In Act II or The Looters, the anomalous portrayals of marital and parental love are complemented by images of greed for property, pillaging, looting and negligence towards the suffering of others. Mr. and Mrs. Dung Beetle enter the stage rolling their precious ball of dung, loving it more than each other; Mr. and Mrs. Cricket move contentedly into a place made available after its previous inhabitant was butchered; and the Ichneumon Fly is ready to do anything for his daughter.

The values on which the bourgeois society is established (hard work, care for the offspring, accumulation of property) are mercilessly derided in this act. Especially here, the expressionist Die Verwandlung (Metamorphosis) (1915) by Franz Kafka (1883-1924) is of interpretative relevance. The selfish and often brutal protagonists of The Looters may be seen as the dramatic equivalents of the bourgeois family of Samsas in Die Verwandlung. (Kafka's insect-turned Gregor is actually the most human character in Metamorphosis, and the actions taken by his family, especially by the parents, imitate the merciless, instinctive behaviour of insects towards anomalous members of their species.)

Also, in Act III or The Ants, various expressionist models are evoked (Opelík 2017: 211). The characters of ants embody the speed and dynamics with which expressionists were fascinated, and the act consists of brief, violent comportments. The breath-taking tempo and the sequence of non-psychological actions which the Wanderer abhors evoke the encounter of Agnes with human cruelty in Ett drömspel (A Dream Play) (1902) by August Strindberg (1849-1912). (The 


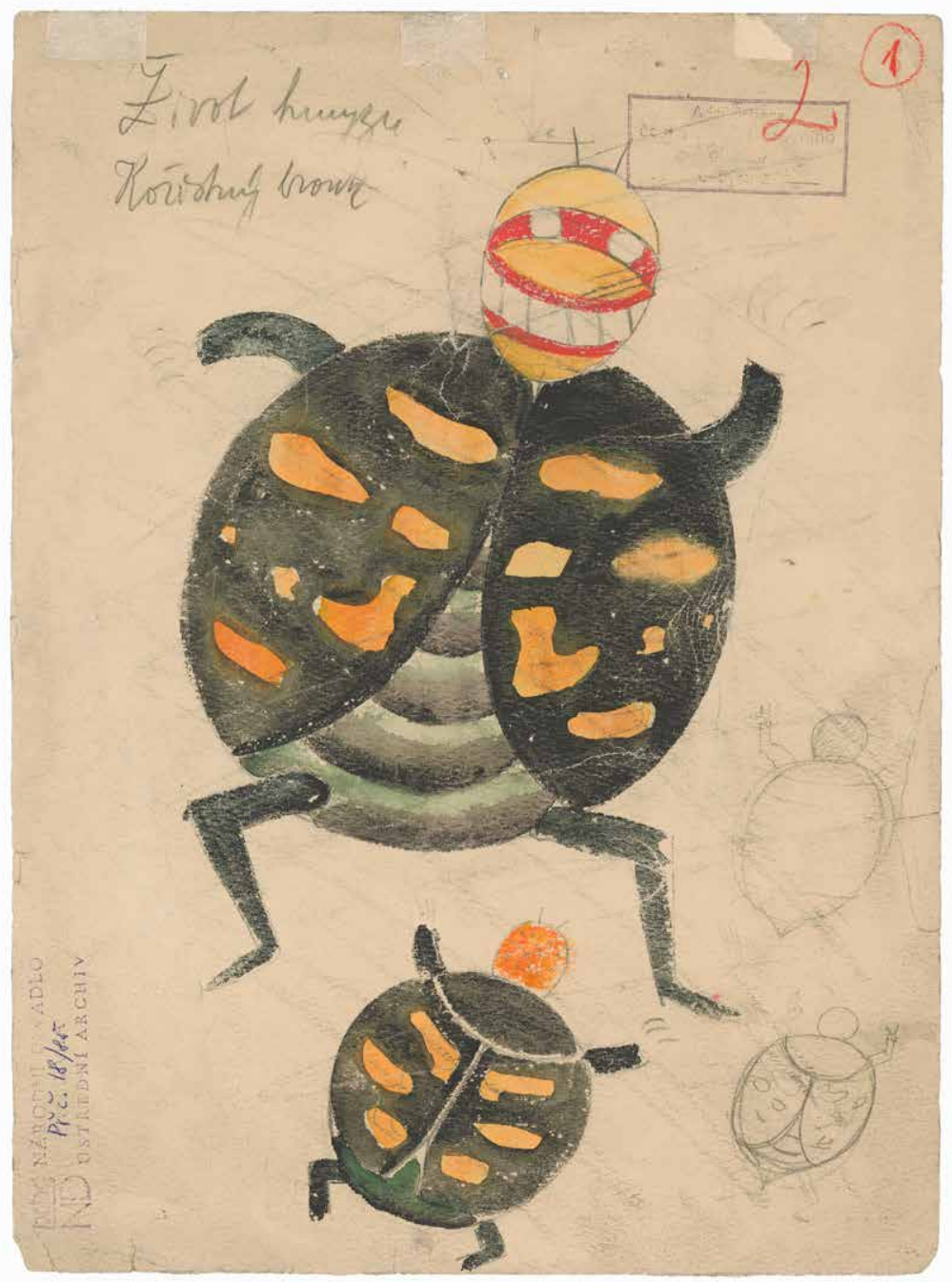

Fig. 5. The sketch of the Looter Beetle for the first staging of From the Insects' Life by Josef Čapek (The Archive of National Theatre, Prague) 
structure of this particular Strindberg's play is also fragmented and just like From Insects' Life, it follows the pattern of Stationendrama).

The Ants also embody the terrifying "insect" disposition of organised masses such as the workers of great industrial factories, the anonymous soldiers in modern-world armies, etc.

\section{The Human/Insect Configuration in From Insects' Life and Its Models}

In the authorial note after the Dramatis personae list (Čapkové 1922b: 7), which was quoted in full length in section 2.3, the characters of the play are described as having human surface (human clothing) and insect-like gestures and mimics (insect inside). This instruction may be metaphorically related to the very structure of the play, and lend an explication of the mutual configuration between the human and insect figures in it.

The Prologue and Epilogue present a "human frame" within which the play encompasses the "insect inside" of the three Acts. The insect characters are thus in a semantically subdued position to the human characters.

Metonymically, the relations between the human and insect characters of the play may also be seen as an anthropological model, which the play presents: the human characters which shape the Prologue and Epilogue embody searching, fellowship, transcendence and mortality.

Concretely, the Wanderer stands for searching, and observation, the priestlike dancing Mayflies represent both human mortality and capacity for transcendental perspective, Woodcutter(s) represent work and the participation in human society, Baptismal Mother with a child and the School-girl represent the circle of life (both female figures are omitted from the second version of the ending) and the Pilgrim represents philosophical and transcendental search.

The insect characters of Butterflies, Looters and Ants in Acts I, II and III embody deformed erotic love, deformed care for property and posterity and deformed nationhood, collectiveness and defence of territory respectively.

(As the Čapeks pointed out in their article for New York Herald (Čapkové 1968: 202-203), the fact that the play presents deformities does not exhaust its perspective on humanity, nor does it negate its positive features and characteristics).

\subsection{The Mise-en-Abyme}

In the suggested anthropological model, the transcendental and philosophical capacities of humanity are balanced by the limits of human mortality (Prologue and Epilogue), but also clearly dominate over the insect vices (Act I, Act II, Act 
III). The vices appear only after the drama "zooms in" the microcosm of the insect lives. The human protagonist is still present in the role of an observer, but also in the role of one who suffers by what he has to observe.

This aspect of the play is actually highlighted in the 1923 English translation by Paul Selver, who (unlike the Czech authors) introduced the play with a poem by Jonathan Swift (1667-1745): "So, Naturalists observe, a flea / has smaller fleas that on him prey; / And these have small still to bite 'em / And so proceed ad infinitum." Paul Selver used Swift's poem also for the subtitle he gave to Čapeks' play: "And so ad infinitum." The poem and the subtitle indirectly point to the abusive, negative aspects of the insect-like behaviour, and also to the mise-enabyme structure.

While Selver's translation is actually not a translation, but an adaption, the Swiftian reference is indeed valuable. Via Swift, it actually evokes the seventeenth and eighteenth century and its fondness of mise-en-abyme both in literature and fine arts. It also evokes Swift's congenial illustrator William Hoghart (1697-1764). In Hoghart's famous mise-en-abyme paintings, the surface of human actions is often reflected by pictures or mirrors, which uncover the true nature of a scene or a character. Piers Beirne characterises Hoghart's style as a "style of art based on iconoclastic comedy and savage satire" and as one leaning also heavily "on seventeenth century animal iconography" (Beirne: 142).

Hoghart's use of mise-en-abyme serves similar purposes as the mise-enabyme in From Insects' Life by the Brothers Čapek. It allows the recipient to comprehend the relation between the human framing and the non-human (beast-like or insect-like) inside.

\subsection{The Human Protagonist as One of the Mayflies}

The only insects capable of stepping outside the mise-en-abyme situation of the insect world are the Mayflies and the Chrysalis. In the configuration of the play, these "occupy" a very specific position.

In the Epilogue, the dancing Mayflies appear as a mysterious answer to the Wanderer's search for light. As they dance, they perform a sort of liturgy and recite a continued hymn which celebrates the mystery and greatness of life; having pronounced her part, each reciter drops down dead. The hymn, however, is immediately continued by another one. It is precisely at this moment that the Chrysalis is finally "born." As one of the Mayflies she joins in the worship, announcing that she will reveal a great mystery. Before she pronounces it, she dies. All of a sudden, the Wanderer is no more in a position of an observer, but desperately, he carries the dead Chrysalis-Mayfly on his arms and mourns for her. Soon, he himself is attacked by the invisible Death. 
In his struggle with him, he actually continues the Mayflies' hymn, pronouncing his acceptance of life, his final understanding of it, and his desire to live. Yet, his death is inevitable. After the Wanderer dies, the first, original version of the ending symbolically points to a new-born child carried to baptism and to a Pilgrim figure as to two characters in which the Wanderer returns, both on the physical and spiritual level.

The hymn recited by the Mayflies in the Epilogue (and valid in both endings) serves as complementation of the semi-philosophical, semi-drunken monologue of the Wanderer in the Prologue. In it, the Wanderer introduces himself not by a name, origin or a profession, but only by the title "člověk" (a human being, a person). Yet, within the individual Acts, the Wanderer is occasionally mistaken for a beetle (by a flirting butterfly in Act I, by Mrs. Cricket who got startled by his remark in Act II, by the ants in Act III). In Wanderer's rhymed comments, the "accidental" comparison between the humans and insects also appear. As a figure with no name or past, the Wanderer may be seen as Everyman. Thus, he is also related to the numerous characters of "common men," pilgrims or wayfarers, which appear in the early short-stories by Josef Čapek and who represent a pure, unstained and questing human type.

The philosophical ending of the play, which used Wanderer's death as a means to generalise his fate, was not comprehensible to most of the audience. Instead, Wanderer's death became the grounds for a critique of the pessimist ending of the play. Pressured to make their philosophy more understandable, the authors wrote a second ending in which the Wanderer wakes from a dream and accepts the offer to join woodcutter's work. The acceptance of both life and death was thus replaced by the acceptance of the life as a mystery, of which all can partake and in which each task has its irreplaceable value.

\subsection{Jean-Henri Fabre and the Unexplored Impetus for Čapeks’ Insects}

The significance of observation relates the play by the Brothers Čapek to La Vie des Insects (The Life of the Insects) (1910) and Souvenirs Entomologiques (Entomological Memories) (series btw. 1879-1909) by Jean-Henri Fabre (1823-1915). Čapeks themselves pointed out: “The comedy From Insects' Life found its impetus in the reading of Fabre's classical works..., namely in the chapters on the fascinating family of the digger wasps (Sphex); and the title of the play itself is a bow to Fabre" (Čapkové 1922a: 202; italics added). Jean-Henri Fabre, sometimes called "the insects' Homer," was a unique type of a scientist, illustrator and writer. Tellingly, his own inspiration for the study of insects came from a literary work: he "discovered insects reading the seventeenth-century French fabulist and poet Jean de La Fontaine" (Slézec 228). 
Fabre's artistic and narrative technique and his precise illustrations were the result of attentive, long-term insect observations. These, in turn, were backed by his philosophical grounding (he was a strong believer) and subtly related to the principles of human life. Besides the capacity to describe the insect behaviour in a nail-biting way, Fabre's style is characterised by his mastery in posing questions. His descriptions, illustrations and queries allow the intuition of natural principles and order of life which surpass the individual existence. The multiple links between his works and the drama have, paradoxically, not been fully explored as of yet (partly due to the lack of Czech translations of Fabre's books).

\section{Conclusion}

The mutual interaction between the insects and humans in the play can be better understood when the dramatic, literary and scientific pretexts of the drama are closely observed, and when the anthropological model based on the mutual configuration between the human and the non-human (acts) of the play is employed.

The Čapeks themselves point out that on the stage, it is either possible to perceive the human characters of From Insects' Life as humans who have acquired some insect qualities (insect morality applied on humans) or the insects as having shared features with the humans (human morality applied on insects).

As for the command of the play, two almost opposing conceptions are possible. Either the keynote lies in the fact that a particular human social type declares themselves either the Sabre Wasp or Mr. Beetle ... suggesting that we, people, are the characters of an insect comedy.... The other conception finds the paradox of the play in its insect, non-human expression, and is much more demanding of the directorial phantasy. There, the humans act as insects. Here, the insects act as humans. (Čapkové 1922a: 203; translation mine)

\section{| Works cited}

Beirne, Piers. "Hogarth's Animals." Journal of Animal Ethics 3.2 (2013): 133162. JSTOR, https://tinyurl.com/77fft7db. Accessed 20 January 2021.

Čapkové, Bratři (The Brothers). “Poznámky k Životu hmyzu.” Jeviště 3.14 (1922a): 202-203.

---. Ze života hmyzu. Praha: Aventinum, 1922b (3rd edition). 
Čapek, The Brothers. “The Insect Play: And So Ad Infinitum.” R.U.R.: Rossum's Universal Robots; The Insect Play: And So Ad Infinitum. Trans. Paul Selver. Eds. Nigel Playfair and Clifford Bax. Oxford: Oxford University Press, 1961. Čapek, Karel (Čapek, Josef). “The Insect Play.” Čapek Four Plays. Trans. Peter Majer and Cathy Porter. London: Methuen Drama (Bloomsbury Publishing Group), 1999.

Čapkové, Karel a Josef. “O pesimismu hry Ze života hmyzu.” Čapek, Karel. Divadelníkem proti své vůli. Praha: Orbis, 1968. 202-203. (first published in New York Herald, 1923, February 2)

Černý, František. "Czech Drama in Prague in the First Years of the Czechoslovak Republic." Ibid. The Czech Theatre 2, Prague: Univerzita Karlova (1995): 7-20, https://tinyurl.com/55f88max. Accessed 13 January 2021.

Černý, František. “Ze života hmyzu." Premiéry bratří Čapků. Praha: Hynek (2000): 107-176.

Garshin, Vsevolod: “That Which Was Not.” Trans. Leo Weiner. https://tinyurl. com/crghez86. Accessed 13 January 2021.

Jakobson, Roman. "Ruský pramen české komedie." Poetická funkce. Praha: H\&H (1995): 557-561. Originally published as "Russkiy istochnik cheshskoy komedii." Ricerche slavistiche 1, Florence and Rome, 1962. 331-335.

Janoušek, Pavel. Rozměry dramatu. Praha: Panorama, 1989.

---. Studie o dramatu. Praha: Ústav pro českou a světovou literaturu, 1993.

Keesmann-Marwitz, Anna Hendrika. “'To, čego ne bylo': Some Thoughts on Garshin's First Animal Tale." Russian Literature 37.4 (1995): 497-504.

Opelík, Jiř́. Josef Čapek. Praha: Triáda, 2017 (first published Melantrich, 1980).

Patridge, James. "Karel Čapek." Encyclopaedia of Literary Translation into English. Slézec, Anne-Marie. "Jean-Henri Fabre: unveiling the fascinating world of insects." Medicographia 38.2 (2016): 220-232. https://www.medicographia. $\mathrm{com} / 2017 / 03 /$ jean-henri-fabre-unveiling-the-fascinating-world-of-insects/. Accessed 8 January 2013.

Photographs and sketches from the Archival file sign. $\check{C} 1325 \mathrm{a}$ are used with the kind permission of The Archive of the National Theatre in Prague (archiv.narodni-divadlo.cz/inscenace/928). 


\section{| Abstract}

KLÁRA Kudlová

The Human and the Non-Human in Čapeks' Ze života hmyzu: Contexts, Scheme, Interpretation

In search for interpretation of the mutual relationship between the human and natural protagonists of Karel and Josef Čapeks' Ze života hmyzu/From Insects' Life (published 1921, staged 1922), the present study uses contextualisation as the primary departure point. The contexts which support the interpretation in section 2 range from the symbolist L'Oiseau Bleu by Gustav Maeterlinck, short prose Chego nie bylo by Vsevolod Garshin, to the popularised scientific observations by Jean-Henri Fabre in section 3.3. In the interpretation of the insect characters and their relation to the human ones, the authorial note on the insects is also employed, opening the sphere of visual inspirations of insects. Josef Čapek's drafts of costumes, physiognomia by Charles Le Brun, and paintings by William Hoghart support the argumentation in section 3. The conclusions drawn in the previous parts of the study are complemented by the structural analysis of the play which deals especially with the employment of the mise-en-abyme principle. The complementation between the human and non-human proves to be key part of this model.

Keywords: Karel Čapek, Josef Čapek, Ze života hmyzu, The Insect Play, non-human characters in drama, mise-en-abyme

\section{| Abstrakt}

\section{Klára Kudlová}

\section{Ludzkie i nie-ludzkie w Ze života hmyzu: konteksty schematy, interpretacja}

W ramach interpretacyjnych poszukiwań wzajemnej relacji między ludzkimi i zwierzęcymi bohaterami sztuki Karela i Josefa Čapków Ze života hmyzu / Z życia owadów (opublikowanej w 1921 roku, a wystawionej w 1922 roku) punktem wyjścia rozważań w niniejszej pracy jest kontekstualizacja. Konteksty, które posłużą za podstawę interpretacji w części 2, sięgają od symbolistycznego Błękitnego Ptaka Gustava Maeterlincka, przez krótki utwór prozą To, czego nie było Wsiewołoda Garszyna, aż po popularyzatorskie rozważania naukowe Jeana-Henriego Fabréa w części 3.3. $\mathrm{W}$ analizie postaci owadów i ich relacji z postaciami ludzkimi wykorzystano również autorską notę na temat owadów, która przybliża sferę plastycznych inspiracji 
światem insektów. Szkice kostiumów Josefa Čapka, fizjonomie Charles’a Le Bruna i obrazy Williama Hogharta stanowią dodatkowe źródło argumentacji w rozdziale 3. Dopełnieniem konkluzji sformułowanych w poprzednich częściach pracy jest analiza strukturalna utworu, która obejmuje przede wszystkim kwestię zastosowanej zasady mise-en-abyme. Kluczowym elementem tego schematu konstrukcyjnego okazuje się wzajemne dopełnianie się tego, co ludzkie, i tego, co nie-ludzkie.

Słowa kluczowe: Karel Čapek, Josef Čapek, Ze života hmyzu, The Insect Play, nieludzkie postacie w dramacie, mise-en-abyme

\section{| About the Author}

Klára Kudlová is assistant professor at CTF CU, Prague. She studied English, American and Czech philology at PF CU in Prague (Ph.D. 2011). Since 2006, she works in the Department for Research into 2oth Century and Contemporary Literature at the ICL CAS and specialises in contemporary Czech prose and drama. Since 2019, she lectures at the Department of Ecclesiastical History and Literary History of CTF CU. She contributed to monographs on contemporary Czech literature (e.g. Rozpad Rakouska-Uherska a jeho di̊sledky pro literatury a kultury střední Evropy, 2019; V souřadnicích mnohosti. Česká literatura první dekády 21. století v souvislostech a interpretacích, 2014). She has published her studies in magazines such as Theatralia, World Literature Studies, Porównania. The author thanks The Archive of the National Theatre in Prague for permission to use visual images.

E-mail: kudlova@ktf.cuni.cz, kudlova@ucl.cas.cz

ORCID: oooo-0003-2253-6888 